\title{
Article
}

Arq Neuropsiquiatr 2011;69(6):928-931

\section{Patients with sudden onset headache not meeting the criteria of the International Headache Society for new daily persistent headache}

\author{
How to classify them?
}

Paulo Hélio Monzillo, Patrícia Homsi Nemoto

\begin{abstract}
We conducted a retrospective analysis of the records of 1348 patients regularly treated at the headache clinic of Department of Neurology of Santa Casa de São Paulo, Brazil. Sixty-two patients reported history of daily and persistent headache. From the 62 patients selected, only 21 (group 1) could be diagnosed with new daily-persistent headache (NDPH) according to the International Headache Society (HIS) 2004 criteria. The 41 remaining patients (group 2) could not be diagnosed with NDPH according to IHS-2004 once they presented two or more migraine attack-related symptoms, such as: nausea, photophobia, phonophobia and vomiting, in different combinations. It was not possible to classify them in groups 1 to 4 of primary headaches either. How to classify them? We suggest that the criteria are revised. And one way we can classify them, would be the subdivision: NDPH with migraine features and without migraine features that would allow the inclusion of all individuals present who has a daily and persistent headache from the beginning
\end{abstract}

Key words: chronic daily headache, headache, chronic tension-type headache, migraine, new daily-persistent headache, International Headache Society criteria.

Pacientes com cefaleia persistente e diária desde o início que não preenchem os critérios da International Headache Society. Como classificá-los?

\section{RESUMO}

Realizamos uma análise retrospectiva do prontuário de 1348 pacientes acompanhados no ambulatório de Cefaleia do Departamento de Neurologia da Santa Casa de São Paulo, Brasil. Sessenta e dois pacientes relataram história de cefaleia persistente e diária (NDPH) desde o início. Destes, apenas 21 (grupo 1) puderam ser diagnosticados com NDPH de acordo com os critérios da Sociedade Internacional de Cefaleia 2004. Os 41 pacientes restantes (grupo 2) não puderam ser diagnosticados como NDPH, uma vez que apresentaram dois ou mais sintomas relacionados a cefaleia do tipo enxaqueca, tais como: náuseas, fotofobia, fonofobia e vômitos, em diferentes combinações. Não foi possível, também, classificá-los entre os grupos de 1 a 4 das cefaleias primárias. Como classificá-los? Sugerimos que os critérios sejam revistos. E uma maneira de podermos classificá-los seria a subdivisão da NDPH em: com características de enxaqueca e sem

\section{Correspondence}

Patricia Homsi Nemoto

Rua Aureliano Coutinho 338 / 95

01224-020 São Paulo - Brasil

E-mail: patnemoto@me.com

Received 18 January 2011

Received in final form 10 August 2011

Accepted 17 August 2011 características de enxaqueca. Isso permitiria a inclusão de todos os indivíduos portadores de uma cefaleia diária e persistente desde o início

Palavras-Chave: cefaleia crônica diária, cefaleia do tipo tensional crônica, enxaqueca, cefaleia persistente e diária desde o início, critérios Sociedade Internacional de Cefaleia.

Headache Clinic of Department of Neurology of Santa Casa de Misericórdia of São Paulo, School of Medicine, São Paulo SP, Brazil. 
Vanast ${ }^{1}$ was the first author to describe in 1986 the new daily-persistent headache (NDPH) as a benign form of chronic daily headache (CDH). In 1996, Silberstein and coll. ${ }^{2}$ proposed diagnostic criteria for this primary headache as the NDPH was not part of the 1988 International Headache Society (IHS) classification ${ }^{3}$.

In 2004, the IHS ${ }^{4}$ established the following diagnostic criteria for NDPH: headache that is daily and unremitting from very soon after onset (within three days at most). The pain is typically bilateral, pressing or tightening (nonpulsating) in quality and of mild to moderate intensity. Photophobia, phonophobia, nausea and pain intensity are not aggravated by routine physical exercises. The symptoms must be present for more than three months and may not be attributable to other causes. Headaches secondary to cerebral spinal fluid (CSF) hypotension, CSF hypertension, post-traumatic headache and headaches attributed to infectious clinical conditions (especially in the presence of infectious agents) must always be excluded through adequate investigation. The IHS (2004) also establishes that the NDPH can progress during a period of time into two different clinical pictures: one self-limiting subform which typically resolves without therapy within several months and a refractory subform which is resistant to any type of treatment. The IHS also suggests that further research studies are required to better characterize the clinical characteristics of NDPH and suggests possible pathophysiological mechanisms, in an attempt to definitely separate NDPH from the chronic tension- type headache (CTTH).

Few reports are available in the literature with large groups of patients with $\mathrm{NDPH}^{1,5}$. The etiology remains unknown ${ }^{6}$, although some authors have tried to establish a temporal relationship to infectious conditions, especially to the Epstein-Barr virus (EBV) ${ }^{7-9}$.

The purpose of our work is to describe the clinical characteristics of the daily persistent headache presented by our patients and to correlate them with the criteria established by the IHS-2004.

\section{METHOD}

After the analysis of 1348 patient records followedup in our headache clinic, 62 cases reporting history of daily and persistent headache since the beginning were selected. None of these patients had previous history of headache.

From the 62 patients selected, only 21 (group 1) could be diagnosed with NDPH according to the IHS-2004 criteria. The characteristics of the headaches and symptoms of the attacks of the remaining 41 patients (group 2) were analyzed in an attempt to classify them into other forms of primary headache.

The study was approved by the ethical committee number 201/2004.

\section{RESULTS}

A total of 62 medical records were evaluated (Table). Thirty-six patients (58.1\%) were women. The average age at the onset of the symptoms was of 40.5 years. Women $(36.7 \pm \mathrm{SD})$ were slightly younger than men $(44.3 \pm \mathrm{SD})$.

The average time delay between the initial symptoms and the first visit to our clinic was of $5.9( \pm \mathrm{SD})$ years. Bilateral pain occurred in 45 patients $(72.6 \%)$.

Pulsating-type pain was present in $43 \%$ of the patients, followed by stabbing pain in 14 patients (22.6\%), "pressing" pain in 12 patients (19.4\%), "tightening" pain in 4 patients (6.5\%), and "burning" pain in three patients (4.8\%). Two patients (3.2\%) referred different types of pain during separate attacks (tightening and pulsating).

Strong to moderate intensity attacks were present in equal percentages $(46,8 \%)$ within our sample, and mild attacks were present in four patients (6.4\%).

Two patients reported autonomic symptoms related to the attacks. Fifty-five patients (56.5\%) were submitted to a complementary investigation and a temporal relationship to the initial symptoms could be established only for three of these patients. Two patients reported a background headache after cranial-cerebral traumatism and one patient after an otomastoiditis complication.

Cranial computerized tomography (CT) was not useful in detecting findings which could justify the clinical symptoms. In the mastoidectomy patient, the CT showed only an area of hypoattenuation in the right temporal region, adjacent to the mastoidectomy. In the remaining patients, radiological and laboratorial findings included the following: a venous angioma (right frontal)

Table. Symptoms of 62 patients who were evaluated.

\begin{tabular}{lcc}
\hline Symptoms & $\mathbf{n}(62)$ & $\%$ \\
\hline $\mathrm{Pt}$ & 2 & 3.2 \\
$\mathrm{~N}$ & 8 & 12.9 \\
$\mathrm{Pn}+\mathrm{Pt}$ & 8 & 12.9 \\
$\mathrm{Pn}+\mathrm{Pt}+\mathrm{N}$ & 7 & 11.3 \\
$\mathrm{Pn}+\mathrm{Pt}+\mathrm{N}+\mathrm{V}$ & 6 & 9.7 \\
$\mathrm{~N}+\mathrm{V}$ & 3 & 4.8 \\
$\mathrm{Pt}+\mathrm{N}$ & 1 & 1.6 \\
$\mathrm{Pt}+\mathrm{Pn}+\mathrm{O}$ & 5 & 8.1 \\
$\mathrm{Pt}+\mathrm{N}+\mathrm{O}$ & 4 & 6.5 \\
$\mathrm{Pt}+\mathrm{Pn}+\mathrm{D}$ & 1 & 1.6 \\
$\mathrm{~N}+\mathrm{D}$ & 1 & 1.6 \\
$\mathrm{Pt}+\mathrm{Pn}+\mathrm{N}+\mathrm{V}+\mathrm{O}$ & 3 & 4.8 \\
$\mathrm{AP}$ & 2 & 3.2 \\
$\mathrm{D}$ & 1 & 1.6 \\
AS & 11 & 17.7 \\
\hline
\end{tabular}

Pt: photophobia; N: nausea; Pn: phonophobia; V: vomiting; O: osmophobia; D: dizziness; AP: autonomic phenomenon; AS: absence of symptoms. 
and a left frontal cavernoma, detected by magnetic-resonance imaging (MRI). In one patient, the laboratorial investigation showed a positive serology test for HIV virus, however without acquired immune deficiency syndrome -AIDS- defining conditions.

In group $1(\mathrm{n}=21), 11$ patients $(17.7 \%)$ did not refer any symptoms associated to the attacks, two patients presented only photophobia and 8 patients referred nausea as an isolated symptom.

Patients of group $2(n=41)$ presented the association of at least two or more headache symptoms in different combinations, such as: nausea, vomiting, photophobia or phonophobia) which excluded the NDPH diagnosis.

\section{DISCUSSION}

Although there are few reports about this type of headache in the literature, NDPH is a part of the IHS classification since 2004, listed in group 4 - other primary headaches ${ }^{4}$. The major characteristic of the NDPH is a daily and unremitting headache.

Although some patients cannot correlate the initial symptoms to any cause, most of them know exactly the onset date, even though it was some time ago. Some authors suggest that the initial headache occurs in relation to temporal viral conditions, infections, extra-cranial surgeries or stressing life events ${ }^{6,10-12}$.

This did not occur in any of our 21 patients meeting the IHS criteria for NDPH and in the 41 patients who, although presenting daily and persistent headache from the beginning, did not meet the IHS criteria. There was no (spontaneous) report suggestive of viral infections at the time of the initial symptoms.

It was not possible to establish the exact time of the onset of the symptoms for the 62 patients evaluated in our clinic. This fact is probably due to the long time elapsed between the onset of the symptoms and the first visit (5.9 years).

More than half of the patients (56.5\%) of our sample were submitted to a complementary investigation which rarely contributed to the diagnostic elucidation. The remaining patients did not have a neuroimaging investigation because they were referred to our clinic many years after the onset of the symptoms and the clinical and neurological exams did not show any abnormalities.

The onset of the symptoms could be attributed to a putative causal factor for only three patients. During this analysis, we could observe the predominance of female patients with NDPH, as previously shown by Vanast and Li and Rozen. Only two recent studies reported a higher incidence of NDPH in men. This predominance in women is still not well explained in the literature $e^{1,6,7,11}$.

The women presented the initial headache prematurely in relation to the men, data which is in line with the literature ${ }^{6}$. These demographic data were not mentioned in the IHS criteria either.

Most of our patients presented a bilateral headache, comparable to the observations by de Li and Rozen and Takase and coll., who also described the bilateral pain in accordance with the IHS criteria, although this criterion is not mandatory ${ }^{4,6,12}$. Pulsating pain was reported in $43.5 \%$ of the patients. Various authors also described pulsating pain as the most common pain in patients with $\mathrm{NDPH}^{5,6,11,13}$.

Li and Rozen ${ }^{5,6}$ had already suggested a variation of pain intensity between moderate and severe as one of the diagnostic criteria of the NDPH. Nearly half of our patients (46.8\%) classified the intensity of their attack as being severe. Ninety three percent of our patients classified their pain as severe or moderate, going against IHS criteria.

According to the IHS criteria-2004, in our casuistic more than $50 \%$ of patients did not meet the criteria for NDPH. Does exist NDPH $?^{14,15}$

The exclusion of migraine features takes a impairment in treatment of these patients as well as understanding the pathophysiology of this entity, as has been demonstrated by Bigal et al. ${ }^{16,17}$.

We agree with the recent publication by Robbins et cols. ${ }^{18}$ and in another words by Young :

"...Current International Classification of Headache Disorders (ICHD) 2 criteria3 exclude the majority of patients with primary headache unremitting from onset. The proposed criteria for revised new daily-persistent headache definition not excluding migraine features (NDPH-R) classify these patients into a relatively homogeneous group based on demographics, clinical features, and prognosis"19.

In conclusion, according to the IHS-2004 criteria, from the 62 patients evaluated and reporting daily headache from the beginning for at least three months with no previous history of headache, only 21 patients (33.8\%) could be classified as presenting NDPH.

The 41 remaining patients $(66.2 \%)$ could not be diagnosed with NDPH according to IHS-2004 once they presented during attack two or more migraine related symptoms, such as: nausea, photophobia, phonophobia and vomiting, in different combinations. To be diagnosed with NDPH, the patient may only present one of these symptoms isolatedly. It was not possible to classify them in groups 1 to 4 of primary headaches either.

\section{How to classify them?}

We suggest that the criteria are revised. And one way we can classify them would be: NDPH with migraine features and without migraine features. That would allow the inclusion of all individuals present who has a daily and persistent headache from the beginning 


\section{REFERENCES}

1. Vanast WJ. New daily persistent headaches: definition of a benign syndrome. Headache 1986;26:317.

2. Silberstein SD, Lipton RB, Sliwinski M. Classification of daily and near-daily headaches: field trial of revised HIS criteria. Neurology 1996;47:871-875.

3. Headache Classification Subcommittee of the International Headache Society. The International Classification of Headache Disorders, $2^{\text {nd }}$ Edition. Cephalalgia 2004;24(Suppl):S1-S160.

4. Headache Classification Subcommittee of the International Headache Society. Classification and Diagnostic criteria for headache disorders, cranial neuralgias and facial pain. Cephalalgia 1988;8(Supp7):S1-S96.

5. Rozen TD. New daily persistent headache. Curr Pain Headache Rep 2003;7: 218-223.

6. Li D, Rozen TD. The clinical characteristics of new daily persistent headache. Cephalalgia 2002;22:66-69.

7. Grande RB, Aaseth K, Lundqvist C, Russel MB. Prevalence of new daily persistent headache in the general population.The Akershus study of chronic headache.Cephalalgia 2009;29:1149-1155.

8. Diaz-Mitoma F,Vanast WJ, Tyrrel DLJ. Increased frequency of EpsteinBarr virus excretion in patients with new daily persistent headaches. The Lancet 1987;1:411-415.

9. Hamada T, Oshima K, Ide Y, Sakato S, Takamori M. A case of new daily persistent headache with elevated antibodies to Epstein- Baar virus. Jpn J Med 1991;30:161-163.

10. Evans RW, Rozen TD. Etiology and treatment of new daily persistent headache. Headache 2001;41:830-832
11. Takase $Y$, Nakano M, Tatsumi C. Primary new daily persistent Headache (NDPH): clinical characteristics of forty-three cases in Japan. Rinsho Shinkeigaku 2003;43:533-538.

12. Takase $Y$, Nakano M, Tatsumi C, Matsuyama T. Clinical features, effectiveness of drug-based treatment, and prognosis of new daily persistent headache (NDPH): 30 cases in Japan. Cephalagia 2004;24:955-959.

13. Goadsby PJ, Boes C. New daily persistent headache. J Neurol Neurosurg Psychiatry 2002;72:ii6-ii9.

14. Rozen TD. Successful treatment of new daily persistent headache with gabapentin and topiramate. Headache 2002;42:433.

15. Manzoni GC. Does NDPH exist? Some clinical considerations. Neurological Science 2011;32(Suppl 1):S45-S49.

16. Bigal ME. The classification of chronic daily headache in adolescents: a comparison between the second edition of the International classification of headache disorders and alternative diagnostic criteria. Headache 2005;45:582-589.

17. Bigal ME, Tepper SJ, Sheftell FD, Rapoport AM, Lipton RB. Chronic daily headache: correlation between the 2004 and the 1988 International Headache Society diagnostic criteria. Headache 2004;44:684-691.

18. Robbins MS, Grosberg BM, Napchan U, Crystal SC, Lipton RB. Clinical and prognostic subforms of new daily-persistent headache. Neurology 2010; 74:1358-364.

19. Young W. New daily persistent headache: controversy in the diagnostic criteria. Curr Pain Head Rep 2011;15:47-50. 